\title{
STELA D: A SUNDIAL AT COPAN, HONDURAS
}

\author{
María C. Pineda de Carías, ${ }^{a}$ Nohemy L. Rivera, ${ }^{\mathrm{b}}$ and Cristina M. Arguetab \\ aFacultad de Ciencias Espaciales, Universidad Nacional Autónoma de Honduras, Ciudad Universitaria, Tegucigalpa M.D.C., Honduras \\ bepartamento de Arqueoastronomía y Astronomía Cultural, Facultad de Ciencias Espaciales, Universidad Nacional Autónoma de \\ Honduras, Ciudad Universitaria, Tegucigalpa M.D.C., Honduras
}

\begin{abstract}
The Maya of Copan, Honduras used Stela D, its altar, and the surrounding structures as a sundial to record time. Archaeological investigations show that wooden posts and stelae could have been used to measure time and to perform associated rites in the northern sector of the Main Plaza of the Copan Archaeological Park. We constructed a digital model of Stela D to study the shadows cast at different times of day and on different dates of the year, such as solstices, equinoxes, and solar zenith passages. The size and orientation of the shadows may have served as a time marker that ancient residents of Copan used to accurately track the tropical year. We also found evidence that supports the iconographic interpretation of an analogy between serpents' bodies that adorn the figure of the ruler on Stela D and shadows and sun positions on dates of major solar events that form a solar calendar that counts years from winter solstice day.
\end{abstract}

\section{INTRODUCTION}

\begin{abstract}
All developing civilizations exhibit a reverence for the sky and its contents. The cyclic movement of the sun, moon, planets, and stars, represents a kind of perfection unattainable by mortals ... So great was the reliance of the ancients on the sun and the moon that they deified them. Representations of these luminaries adorned their temple as objects of worship, and they were symbolized in sculpture and other works of art. The ancients followed the sun god wherever he went, marking his appearance, and disappearance with great care ... The important days of celebration and festivity could be marked effectively using celestial calendar (Aveni 2001:1-2).
\end{abstract}

The Maya of Copan, Honduras were great sky watchers and sun worshipers. In the Main Plaza of the Copan Ruins Archaeological Park they built and oriented structures, stairways, landings, stelae, and altars to mark sunrises and sunsets on special days of the year such as equinoxes, solar zenith passages, and solstices. These events have been documented and reported in several articles published by the Research Group of Maya Archaeoastronomy of the National Autonomous University of Honduras (Pineda de Carías et al. 2002a, 2002b). After more than fifteen years of studying the north sector of the Main Plaza of the Copan Ruins Archaeological Park, the Department of Archaeoastronomy and Cultural Astronomy (DACA) of the Space Sciences Faculty (SSF) of the National Autonomous University of Honduras (NAUH) now has a well-documented collection of more than one thousand photographic images supporting various investigations (Pineda de Carías and Véliz 2009).

We have identified Stela D, located in the northern sector of Main Plaza of Copan, as a sundial (Pineda de Carías et al. 2009). To show how the Copan Maya used Stela D as a sundial, the group documented observations of the stela's projected shadows at different times of the day on different days of special solar events of the

E-mail Correspondence to: mcpinedacarias@gmail.com tropical year, marking various features, including: structures, stairways, and the altar associated with the stela; the appearance of the sun over the horizon; the position of the sun at different intervals of the day; the highest altitude of the sun in the sky; and the disappearance of the sun over the horizon. The iconography of Stela D, with snake motifs adorning the figure of Waxaklajuun Ubaah K'awiil, the thirteenth ruler of Copan, was associated with the winter solstices, equinoxes, solar zenith passages, and summer solstices to interpret and record the solar events of the tropical year called haab.

\section{STELA D'S ARCHAEOLOGICAL CONTEXT}

Explorations, excavations, and restorations of the northern sector of the Main Plaza of Copan as we find it now were done by the Copan Archaeological Project (CAP) in the late 1970s and early 1980s. As CAP staff has reported (Cheek 1983), the Copan Valley has been a vast field of archaeological research for national and foreign scientists. The Valley contains several thousand structures, many of them concentrated in distinct groups. The Main Group of these structures is divided in two zones, the Acropolis in the south and the Main Plaza to the north. The northern sector of the Main Plaza is delimited by Structures 10L-2 and 10L-4. Here are the major concentrations of stelae. The Main Plaza is closed to the north, east, and west side by a series of stairways that rise from the floor of the plaza to the surrounding platform. The northernmost building, Structure 10L-2, rises in the center of a series of reviewing stands that form the edge of the plaza. At both ends of this area, two platforms, also containing stairways, form the east and west side of the north sector of the plaza. The stairways consist of a series of successive steps, separated by narrow terraces or landings.

According to CAP (Cheek and Kennedy 1983:102), Alfred Maudslay undertook the first exploratory excavations in the northern sector of the Main Plaza in 1855, and archaeologists from the Peabody Museum continued work between 1891 and 1895. 
Cleaning resulted in a gradual destruction of the staircases so that, if pictures had not been taken, it would have been impossible to restore the monument. Furthermore, cleaning the monuments without consolidation permitted vegetation to regrow, in turn displacing and causing stones to slide, facilitating archaeological looting, and hampering preservation. With the excavations and restorations done by the CAP, three main stages of constructions were defined, corresponding to the Structures 2-3rd, 2-2nd, and 2-1st. This latter phase was divided into two phases, labeled A and B.

\section{CONSTRUCTION STAGES IN COPAN'S MAIN PLAZA (NORTHERN SECTOR)}

\section{Structure 2-3rd}

Cheek and Kennedy Embree (1983) reported that the remains of a supposed older building and the construction of a stucco floor in the north sector of the plaza represented the first architectural activities in the Structure 2 zone. Three features of burned clay, probably postholes, were found arranged along the axial line of the structure. One of these features is a conical hole with an important fragment of burned wood in vertical position like a post; the other two features consist of cylindrical holes that probably also contained posts. These holes were covered with rocks and clay and then burned. Cheek and Kennedy Embree (1983) postulated that these posts could have been used during the construction period for retention, or as a support for a roof that protected the work from rains, but also stated that these alternatives did not seem satisfactory to them. Postholes could also be interpreted as burned supports for a wooden sacrificial scaffold, as is found in the Tupp K'ak of colonial Yucatan (Newsome 2003). This ritual involved the sacrifice by fire of a captive lashed to the scaffold, which was burned to the ground (Newsome 2003; Taube 1988 in Looper 2009:70-73). This ceremony, linked to royal ascension, was also central to rainmaking and calendrical ceremonies that involved the intermeshing of the 260-day cycle and the solar year. These posts in the north sector of the Main Plaza may have served as gnomons, or vertical post that casts shadows of different sizes in different directions, as the sun moves across the sky during the day and throughout the year (Pineda de Carías et al. 2009).

\section{Structure 2-2nd}

Cheek and Kennedy Embree (1983:137) reported that the second building defined by the excavations consisted of a trapezoidal structure with two terraces and stairs in two sections with southern orientation. A hiding place or cache location was discovered in the center of the south wall of the lower platform. Here Cheek and Kennedy Embree (1983) found a carved and longitudinally perforated pectoral of jade representing two serpents with interlaced bodies (Figure 1). They also reported that this pectoral represents the only indication of ritual activity in this area. Due to the serpents carved on the pectoral found in this construction phase and the

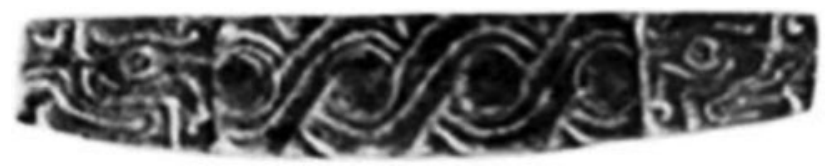

Figure 1. Jade pectoral recovered in the cache in Structure 2-2nd, showing two serpents with intertwined bodies. resemblance shadows cast on the ground by a gnomon have to moving snakes, Pineda de Carías et al. (2009) interpreted this ritual activity as probably related to celebrations of ends or beginning of cycles or periods of time.

\section{Structure 2-1st}

Cheek and Kennedy Embree (1983) reported that important changes happened in the architectural aspect of the north sector of the plaza during this construction phase. The most outstanding alteration was the construction of stairways on each side of Structure 2, whose orientation was altered to deviate slightly from the northern boundary of the plaza. The first stairway was partially removed and partially covered. Stela D and its altar stand opposite the middle axis of the central stairways, placed over a platform attached to the first step of the stairway forming a terrace or landing, which is the starting point of the first step. There are two other landings: one on top of the stairs and the other near the base of the structure. As in Structure 2-2nd, the bottom stairways are wider than the top ones. Two niches forming terraces flank these and, at the narrowest, there is no exit to the east; the west terrace ends in one of the northwest stairway landings. An unusual feature of the northeast and northwest stairways is that their inclinations are not parallel to the central stairway. The northwest line of risers slopes more than the northeast side. During the reconstruction operations, a reused fragment of Stela 17 was discovered incorporated as the second step of the west side of the central stairway. Other pieces of originally carved fragments were also found forming steps. Cheek and Kennedy Embree (1983) reported that this was not unique and that fragments of stelae were repeatedly reused as steps in this structure.

Pineda de Carías et al. (2009) suggest that either carved or plain stelae preceded Stela D. Stelae are more permanent elements than wood posts; the sizes and directions of the shadows cast by different stelae used as gnomons could have given the Copan Maya experience of stelae as astronomical features of the plaza area and allowed them to measure cycles of time with greater precision (Pineda de Carías et al. 2009).

Chronologically, the location of Structure $10 \mathrm{~L}-2$ in its final phase with the north, east, and west stairways enclosing the northern side of the Main Plaza, Stela D, its altar and its platform all date to the Late Classic Period (A.D. 600-900). The date of dedication of Stela D is 9.15.5.0.0 10 Ahau 8 Ch'en, corresponding to A.D. July 22, 736 (Baudez 1994; Newsome 2001). The thirteenth ruler of Copan, called Waxaklajuun Ubaah K'awiil ("18 Rabbit"), whose figure appears carved on the south face of Stela D, is presumed to have been responsible for these phases of construction.

Giving the three-dimensional qualities of Copan's freestanding sculptures, Miller (1999:11) has said, "[m]uch Maya art is site-specific, both in the current sense of being designed for a particular architectural space, but also in the sense of being made within a particular regional school." Large structures demand large plazas. Plazas and platforms were related to stairways that allowed vertical movements. In their texts, the ancient Maya gave names to the things they made. They named their building and monuments and they revered the day when they placed a new stone monument. As is written on its north side, lakantun is the name of Stela D. The north side inscription panel records its name beginning with the stela erection verb t'zap at B5, the monument proper name following at A6-7, and concluding in B6 with the noun for the stela, “lakantun," or "large stone" (Schele and Matthews 1998:169). 
Archaeoastronomy has helped generate and test hypotheses about the role played by the record of time in Maya city planning (Aveni et al. 2003). Using accurate measurements and other data derived from reliable maps corrected by astronomical records, Aveni et al. (2003) analyzed specialized architectural complexes, such as the E Group complex at Waxactun, Guatemala. They suggest that in the Early Classic period (A.D. 200-600), a seasonal calendar originally based on the orientation of structures with the solstice and equinox positions of the sun was reformed and replaced by a calendar derived from Teotihuacan in which buildings oriented to solar zenith passage became predominant. They point out that astronomical alignments in specialized buildings can offer a sense of the way that the architectural space could have been used to accommodate rites marked by time.

We formulated the following questions: (1) how did the Maya measure time, (2) how were important dates marked to generate the basis of their calendars, and (3) was Copan Stela D an instrument to measure and record the time? To answer these questions, we built a virtual model of Stela D, its altar, and adjacent stairways of Structure 10L-2. The objective was to study the patterns of the shadows projected at different times of the day and on different dates of the year, especially on the solstices, equinoxes, and solar zenith passages. As a result, we believe that we can explain how the Maya of Copan used Stela D and associated architecture as a sundial to record and keep track of time. To interpret the iconography of Stela D, we suggest the idea that shadows projected in the shape of serpent bodies allowed Stela $\mathrm{D}$ to pinpoint and mark different days on which solar events took place in a cycle moving north to south. Beginning with a shadow effect moving from north to south, the shadows track a count of days in the winter solstice, continuing with the spring equinox, the first zenith sun passage, and the summer solstice. Moving into this position, corresponding to summer solstice, the shadows then reverse direction and begin to proceed daily from south to north, tracing the sun's progression through the second zenith sun passage, the autumnal equinox, and returning to another winter solstice. Returning to their original position, the shadow orientation once again corresponds to the sun's winter solstice stationary position on the horizon, marking year's end and the beginning of a new annual cycle. These shadow effects correspond to the iconographic serpents carved on the south, east, and west sides of Stela D, which we interpret as symbols for the moving cycle of elongated shadows traced by the patterns of sunlight falling on Stela D throughout the solar year. The serpents interlaced in the headdress of the ruler represent the cycle of the tropical year called haab, which counts the years beginning from the dates of winter solstice.

\section{DESCRIPTION OF THE MODEL}

The Stela D virtual model and its associated structures are described in two phases. First, we built and located the Stela D model and its base as a gnomon on a framework. Then we built the central stairway, the northeast, and the northwest stairways of Structure 10-2, added the altar of Stela D, and finally added the east and west stairways. In what follows, we describe the process in more detail.

\section{Phase I: Construction of the Gnomon}

To construct the model of Stela $\mathrm{D}$ as a gnomon we used SketchUp 8 , the three-dimensional modelling software that is a free download via the Internet. Once we installed the software, we opened a new model initialized by entering Copan Ruins coordinates (latitude: $14.8403 \mathrm{~N}$; longitude: $89.1422 \mathrm{~W}$ ) to specify a geolocation.
As a framework for measuring the shadows of Stela D, we followed the instructions on building sundials available from the website of The Planetary Society (Sullivan et al. 2013). First we calculated the distance $\mathrm{CG}$, in which point $\mathrm{C}$ is the origin of all the hour lines, $\mathrm{G}$ is the geometrical center of the base of Stela D, and CG is the distance equal to the height of the gnomon divided by the tangent of the latitude of Copan. As the height of the gnomon we used Stela D's maximum height (Baudez 1994) plus the height of the base where Stela D is located $(353 \mathrm{~cm}+25 \mathrm{~cm}=378 \mathrm{~cm})$. The distance $\mathrm{CD}=1,426.6 \mathrm{~cm}$. To calculate the angles of the hour lines (B), we used the equation, $\tan B=\sin ($ latitude $) \times$ $\tan \left(H \times 15^{\circ}\right)$, where $\mathrm{H}$ is the hour before or after noon. Table 1 shows the values for different times of day.

Then we calculated the data for drawing curves including dates of Copan's solstices, equinoxes, and zenith sun passages (April 30 and August 11). For each value of $\mathrm{H}$, we calculated $\mathrm{R}$ for the solar declination $\mathrm{D}=-23.4^{\circ}$ (winter solstice), $0^{\circ}$ (spring and autumn equinoxes), $+14.8403^{\circ}$ (first zenith sun passage from south to north and second zenith sun passage from north to south), and $+23.4^{\circ}$ (summer solstice), where $R=[($ gnomon height $) \times \cos D] /[\sin ($ latitude $) \times \cos (F-D)]$ and $F=\tan ^{-1}\left[\tan (\right.$ latitude $\left.) / \cos \left(H \times 15^{\circ}\right)\right]$. These values of $\mathrm{R}$ are the distances along each hour line, measured from point $\mathrm{C}$ to the points of intersection with each date curve. In Table 2, we present these values as distances to the summer solstice (CS), equinoxes (CE), winter solstice (CW), and solar zenith passages (CZ). Then we drew Stela D and its base as an isolated gnomon. When drawing the stela, we tried to keep the shape and volume rather than the details of each of the sides. We positioned Stela D and its base on the hour lines and date curves of solar events drawn

Table 1. Angles of hours for a gnomon located in Copan, Honduras.

\begin{tabular}{lr}
\hline \hline Hours & Degrees \\
\hline 12 (noon) & 0.0 \\
11 A.M., 1 P.M. & 3.9 \\
10 A.M., 2 P.M. & 8.4 \\
9 A.M., 3 P.M. & 14.4 \\
8 A.M., 4 P.M. & 23.9 \\
7 A.M., 5 P.M. & 43.7 \\
6 A.M., 6 P.M. & 90.0 \\
\hline
\end{tabular}

Table 2. Distances for date curves of solar events for a gnomon located in Copan, Honduras.

\begin{tabular}{lcccc}
\hline \hline & $\begin{array}{c}\text { Summer } \\
\text { Solstice }\end{array}$ & Equinoxes & $\begin{array}{c}\text { Winter } \\
\text { Solstice }\end{array}$ & $\begin{array}{c}\text { Zenith Sun } \\
\text { Passage }\end{array}$ \\
\cline { 2 - 5 } Hours & $\begin{array}{c}\text { Distance CS } \\
(\mathrm{cm})\end{array}$ & $\begin{array}{c}\text { Distance CE } \\
(\mathrm{cm})\end{array}$ & $\begin{array}{c}\text { Distance CW } \\
(\mathrm{cm})\end{array}$ & $\begin{array}{c}\text { Distance CZ } \\
(\mathrm{cm})\end{array}$ \\
\hline 12 (noon) & $1,369.7$ & $1,526.8$ & $1,724.5$ & $1,426.6$ \\
11 A.M., 1 P.M. & $1,368.0$ & $1,530.4$ & $1,736.5$ & $1,426.7$ \\
10 A.M., 2 P.M. & $1,362.9$ & $1,543.4$ & $1,778.9$ & $1,427.6$ \\
9 A.M., 3 P.M. & $1,356.1$ & 1576.0 & $1,881.1$ & $1,433.7$ \\
8 A.M., 4 P.M. & $1,358.7$ & $1,670.3$ & $2,167.3$ & $1,464.6$ \\
7 A.M., 5 P.M. & $1,463.7$ & $2,112.1$ & $3,792.0$ & $1,661.4$ \\
6 A.M., 6 P.M. & $3,410.5$ & $5,209,875.7$ & & $5,570.0$ \\
& & & & \\
\hline \hline
\end{tabular}


as reference, placing the center of the base of Stela D at Point G. Then, using the software tool for shadows, we checked the patterns of the shadows of Stela D at different times of the day on the dates of the solstices, equinoxes and solar zenith passages, falling within the margins of the reference date curves previously calculated and drawn.

\section{Phase II. Construction of the Stairways and the Altar of Stela D}

Central Stairway. Since the Central Stairway is completely restored, we measured the three dimensions of the thirteen steps that compose it. With these dimensions, we drew the block of the Central Stairway. In Table 3 we present measured dimensions for each step.

To locate and to orient the Central Stairway in the model we considered two factors. First, we took into consideration Cheek and Kennedy Embree's (1983) explanations that all remodelling activities cause some destruction in earlier structures. The orientation of the middle of the Central Stairway is approximately $264^{\circ}$ 40 ' east of due north. Measured angles were approximate because there are differences in the orientation of each step. Second, we inspected photographs of several years of solar observations of Stela D available at the DACA. The photographs and data show that the day of the winter solstice, from 8:00 A.M. (on December 21 in 2000, 2007, and 2008), the shadow of Stela D falls on the Central Stairway at the third step. As time passes, the shadow shrinks to fall on the first step; at the solar noon time, Stela D and its shadow are seen as a continuum, touching the northern end of the shadow on the southern border of the first step of the Central Stairway. Then the shadow begins to climb until around 4:00 P.M., when the shadow leaves the Central Stairway on the east side of the first steps. Figures $2 \mathrm{a}-2 \mathrm{c}$ present three photographs illustrating this phenomenon of light and shadow.

In light of the criteria mentioned above, we adjusted the orientation of the Central Stairway by $10^{\prime}$ to an angle of $264^{\circ} 30^{\prime}$ to the east of the due north. This caused Stela D's shadows on the day of the winter solstice to fall on the landing of the third step at 8:00 A.M. By midday the shadow was touching the exterior edge of the first step. At 4:00 P.M., the shadow moved from the central sector to the east corner of the first steps.

Table 3. Dimensions of the Central Stairway of Structure 1OL-2.

\begin{tabular}{lcccccc}
\hline \hline & \multicolumn{2}{c}{ Height $(\mathrm{cm})$} & & \multicolumn{2}{c}{ Width $(\mathrm{cm})$} & \\
Step & & & & & \\
Number* & West Side & East Side & & West Side & East Side & $(\mathrm{cm})$ \\
\hline G-1 & 1.0 & 1.0 & & 41.3 & 39.0 & $1,186.0$ \\
G-2 & 39.1 & 43.9 & & 39.3 & 41.4 & $1,192.0$ \\
G-3 & 39.9 & 40.7 & & 184.5 & 213.0 & $1,190.0$ \\
G-4 & 36.4 & 39.8 & & 42.0 & 38.9 & $1,209.0$ \\
G-5 & 37.4 & 40.5 & & 40.4 & 41.8 & $1,220.0$ \\
G-6 & 42.7 & 40.3 & & 39.7 & 39.6 & $1,225.0$ \\
G-7 & 41.2 & 41.2 & & 40.3 & 39.2 & $1,225.2$ \\
G-8 & 38.8 & 41.1 & & 56.0 & 73.0 & $1,230.8$ \\
G-9 & 40.6 & 40.1 & & 39.7 & 39.7 & 747.0 \\
G-10 & 37.8 & 38.0 & & 38.7 & 39.0 & 747.0 \\
G-11 & 37.6 & 37.7 & & 43.7 & 39.5 & 744.6 \\
G-12 & 40.6 & 39.3 & 37.9 & 38.7 & 728.4 \\
G-13 & 38.7 & 37.2 & & 150.7 & 150.7 & 733.4 \\
& & & & & \\
\hline \hline
\end{tabular}

*Numbered from the bottom to the top. (a)

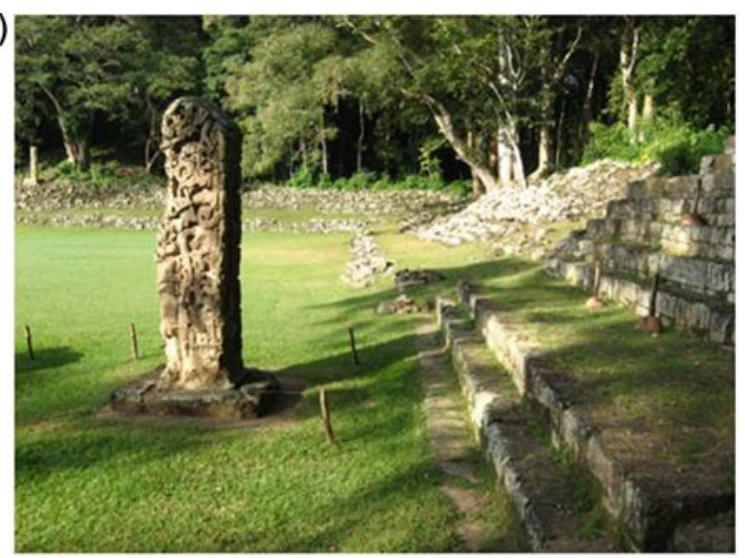

(b)

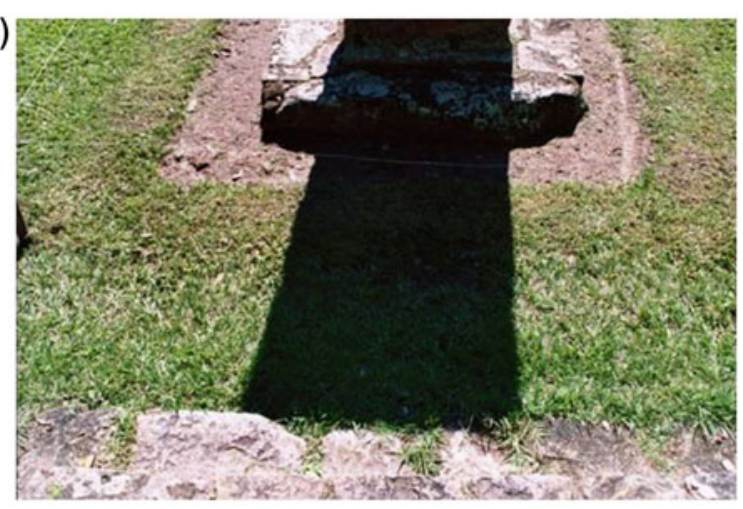

(c)

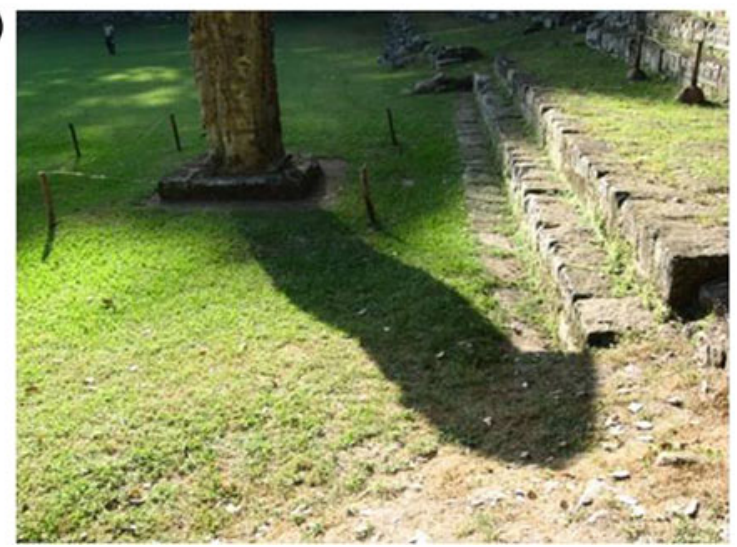

Figure 2. Images of shadows cast by Stela $D$ on the central stairway of Structure 10L-2 on the winter solstice. (a) At 8:00 A.M. the shadow enters the central area on the west side of the landing of the third step; (b) at solar noon, the north end of the shadow touches the outer southern edge of the first step; (c) in the afternoon at 4:00 P.M. the shadow leaves the central sector by the end of the first rows. Photographs courtesy of DACA/SSF/NAUH.

Northeast Stairway. According to Cheek and Kennedy Embree (1983), the northeast sector is composed of a series of successive steps separated by a narrow terrace. Most of the risers have been destroyed by erosion or the stones have been moved by vegetation. In the middle of the first set of risers is a large tree. This sector has never been restored. To build the block of the Northeast Stairway of our model, we followed the distribution pattern of successive staircases, reviewing stands and terraces suggested by Cheek and 
Table 4. Dimensions of the Northeast Stairway of Structure 1OL-2.

\begin{tabular}{lccc}
\hline \hline Step Number* & $\begin{array}{c}\text { Height } \\
(\mathrm{cm})\end{array}$ & $\begin{array}{c}\text { Width } \\
(\mathrm{cm})\end{array}$ & $\begin{array}{c}\text { Longitude } \\
(\mathrm{cm})\end{array}$ \\
\hline G-1 & 23.8 & 60.0 & 3,500 \\
G-2 & 31.0 & 60.0 & 3,500 \\
G-3 & 32.0 & 60.0 & 3,500 \\
G-4 & 43.1 & 251.1 & 3,500 \\
G-5 & 34.3 & 57.0 & 3,500 \\
G-6 & 32.1 & 57.0 & 3,500 \\
G-7 & 38.3 & 57.0 & 3,500 \\
G-8 & 48.5 & no scale & 3,500 \\
& & & \\
\hline \hline
\end{tabular}

*Numbered from the bottom to the top.

Kennedy Embree (1983). Table 4 presents the dimensions of the Northeast Stairway.

We used our judgement to locate and to orient the Northeast Stairway. We learned about the theory and practice of constructing sundials during our experience with the Project Earth Dial related to National Aeronautics and Space Administration's (NASA) Mars Exploration Rovers Mission Spirit and Opportunity. In the Central
American Suyapa Astronomical Observatory (CASAO) of National Autonomous University of Honduras (NAUH), we built a gnomon as part of this project and were able to verify, among other things, that on the day of the spring equinox, the shadow makes a straight line. We had another similar experience using a stone replica of a Copan Maya stela (scale 1:1) placed in the CASAO. With this stela replica, our team observed, year after year, whether spring or autumn, how the tip of the shadow demarcates a straight line at the day of the equinox. On the other hand, from the collection of photographs of DACA combined with data from solar observations, we noticed that at the day of the equinox, the shadow of Stela D, at about 8:00 A.M., meets the southeast corner of the Northwest Stairway of Structure 10L-2. At solar noon, the shadow of Stela D is exactly behind it but is much smaller in size than the winter solstice shadow at the same time; around 4:00 P.M. the end of the shadow touches the west corner of the Northeast Stairway. After this time, the shadow always touches the outer edge of the southernmost stair until the sun sets. Figures 3a-3e illustrate the above-mentioned characteristics. Based on these observations, the block of the Northeast Stairway was placed in the model so that, from 4:00 P.M. until sunset, the tip of the shadow of Stela D always touches the southernmost edge of the Stairway.
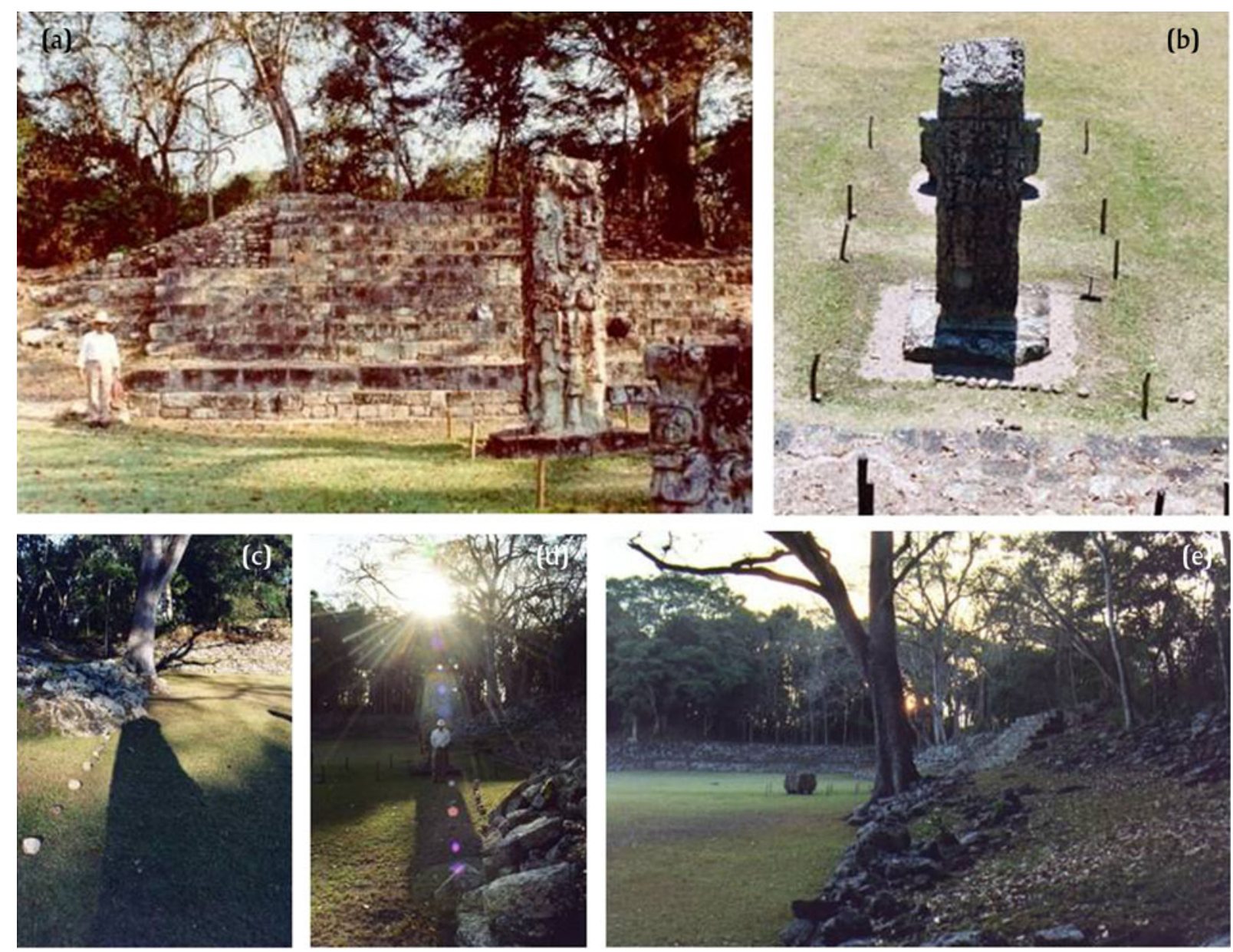

Figure 3. Images of shadows cast by Stela D on the spring equinox. (a) Shadow around 8:00 A.M.; (b) Stela D and its shadow at solar noon; (c) shadow around 4:00 P.M.; (d) shadow around 5:00 P.M.; (e) sunset view from the east end of the Northeast Stairway. Photographs courtesy of DACA/SSF/NAUH. 
Northwest Stairway. This sector, like the Northeast Stairway is completely eroded. According to Cheek and Kennedy Embree (1983), it consists of a series of successive steps separated by a narrow terrace, so for its construction we used the pattern that they suggested. In Table 5 we present the dimensions of the Northwest Stairway.

For the location and orientation of the Northwest Stairway, we followed several criteria. From the DACA photograph collection of solar observations for the zenith sun passage day, we found that on April 30, 2001, April 30, 2002, April 30, 2005 and April 30, 2007, between 6:00 and 8:00 A.M., the tip of the shadow of Stela D drew a parallel line to the direction of the Northwest Stairway. We also noted that, standing at the west end of this Stairway, this seemed to be aligned with the direction of the sunrise. At solar noontime Stela D does not project shadows in any direction. After noon, the shadow always points toward the structures placed on the east platform of the plaza. In Figures $4 \mathrm{a}-4 \mathrm{f}$, we present some photographs showing the features mentioned. The block of the Northwest Stairway was placed in the model parallel to the line drawn by the tip of Stela D shadow between 6:00 to 8:00 A.M.

Stela D Altar. This altar is almost square, with a bicephalic monster carved in high relief on the vertical sides (Baudez 1994). Several traces of red paint indicate that the entire monument originally had this color. Its height (on average) is $110 \mathrm{~cm}$, with an eastwest width (from the top) of $215 \mathrm{~cm}$. The width of each of its sides averages $150 \mathrm{~cm}$. According to our measurements, the altar is located $367 \mathrm{~cm}$ along the north-south axis from the bottom of the south face of Stela D. This value coincides with the distance measured from the same point on the south face of Stela D to the outer edge of the first step of the Central Stairway of Structure 10L-2.

East and West Stairways. To complete the model, we drew the East and West Stairways. Although these stairways are quite eroded, the continuity with respect to the Northeast and Northwest Stairways is still appreciable and therefore this is one criterion used to confirm the number of steps and landings as they have been reconstructed. Each block was constructed separately, giving it a solution of right angles to the intersection with the Northeast and

Table 5. Dimension of the Northwest Stairway of Structure 10L-2.

\begin{tabular}{lccc}
\hline \hline Step Number* & $\begin{array}{c}\text { Height } \\
(\mathrm{cm})\end{array}$ & $\begin{array}{c}\text { Width } \\
(\mathrm{cm})\end{array}$ & $\begin{array}{c}\text { Longitude } \\
(\mathrm{cm})\end{array}$ \\
\hline G-1 & 28.3 & 52.4 & 5,100 \\
G-2 & 40.9 & 52.4 & 5,100 \\
G-3 & 40.9 & 52.4 & 5,100 \\
G-4 & 47.2 & 227.5 & 5,100 \\
G-5 & 30.4 & 39.0 & 5,100 \\
G-6 & 34.6 & 42.8 & 5,100 \\
G-7 & 25.6 & 42.6 & 5,100 \\
G-8 & 32.2 & no scale & 5,100 \\
& & & \\
\hline \hline
\end{tabular}

*Numbered from the bottom to the top.
Northwest Stairway respectively, where we located and oriented them in the model.

\section{RESULTS}

After completing the virtual model, we ran it several times for each hour of the different days of the year. Furthermore, for the four types of solar events of the year, the winter solstice (December 21, 2012 and December 21, 2013), equinoxes (spring [March 20, 2013] and autumn [September 22, 2013]), solar zenith passages (April 30, 2013 and August 11, 2013) and the summer solstice (June 20, 2013), we produced short picture films of four hundred images. This allowed us to study better the patterned effects of the shadows of Stela D and those of its altar on the stairways of the north sector of the Main Plaza of Copan. We explain below the results obtained for each of the major solar events, and we emphasize that the virtual model, to fully include the stairways, allows us to have a vision of what the northern sector of the Main Plaza might have looked like at the time, something that is impossible to imagine both because of the degree of deterioration of the stairways and because of the vegetation that has grown between them.

\section{Winter Solstice}

On the day of the winter solstice, the first rays of the sun appear around 6:23 A.M. At its first appearance, the shadow of Stela D projects on the highest part of the Northwest Stairway of Structure 10L-2. From this moment and for about an hour and a half, the shadow of the stela, following a sloping direction, reduces its size, creating the appearance that the shadow is descending as time passes. Around 8:00 A.M., the shadow of Stela D leaves the Northwest Stairway to overlap the Central Stairway's west end, at exactly the height of the lower landing. It takes about four hours for the shadow to fully descend the first three steps of the Central Stairway. At the time of solar noon around 11:54 A.M., the shadow touches the lower part of the Central Stairway coinciding with the outer edge of the first step; at this moment the shadow extends directly behind Stela D as a prolongation of the monument's north face of the stela that looks dark because, during the day, the sun passes further to the south in crossing the sky. Then, the shadow begins to grow in size, taking another four hours for it to reach the top of the stairs before crossing the end of the first steps of the Central Stairway. From 4:00 P.M. the shadow of Stela D falls on the west end of the Northeast Stairway. Always growing in size and apparently slanting across this Stairway, the shadow ascends until it reaches the stairway's highest point and disappears when the sun sets around 5:20 P.M. This is the shortest day of the year, with a duration of eleven and a half hours of daylight. A selection of seven pictures of the virtual model is presented in Figures $5 \mathrm{a}-5 \mathrm{~g}$, to give a complete panoramic sequence of the shadow patterns of Stela D on the day of the winter solstice.

\section{Spring (Autumn) Equinox}

On the day of the spring (or autumn) equinox, the sun rises around 6:00 A.M. With the first rays of sun, Stela D casts its shadow over the top of the Northwest Stairway of Structure 10L-2. The shadow is long on this day, extending almost twenty meters to the west in relation to the point where the shadow appeared on the same stairway on the date of the winter solstice. For a two-hour 

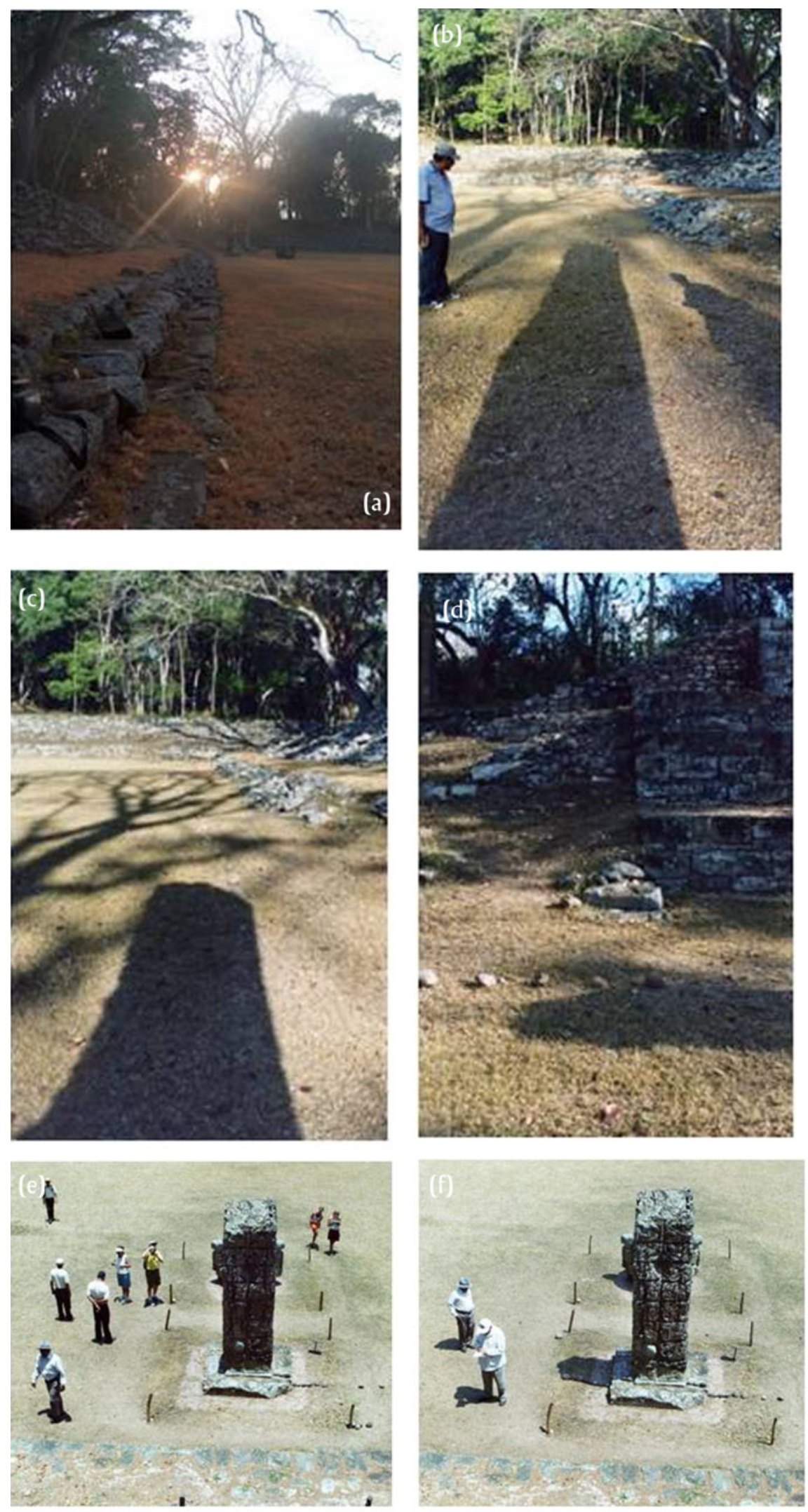

Figure 4. Images of shadows cast by Stela $D$ on the zenith sun passage day. (a) Sunrise, looking in the direction of the Northwest Stairway of Structure 1OL-2; $(\mathrm{b}-\mathrm{c}$ ) shadows of Stela D before 8:00 A.M.; (d) tip of the shadow of Stela D around 8:00 A.M.; (e) noon solar day, no shadow in any direction; (f) Stela D and its shadow in the afternoon. Photographs courtesy of DACA/SSF/NAUH. 

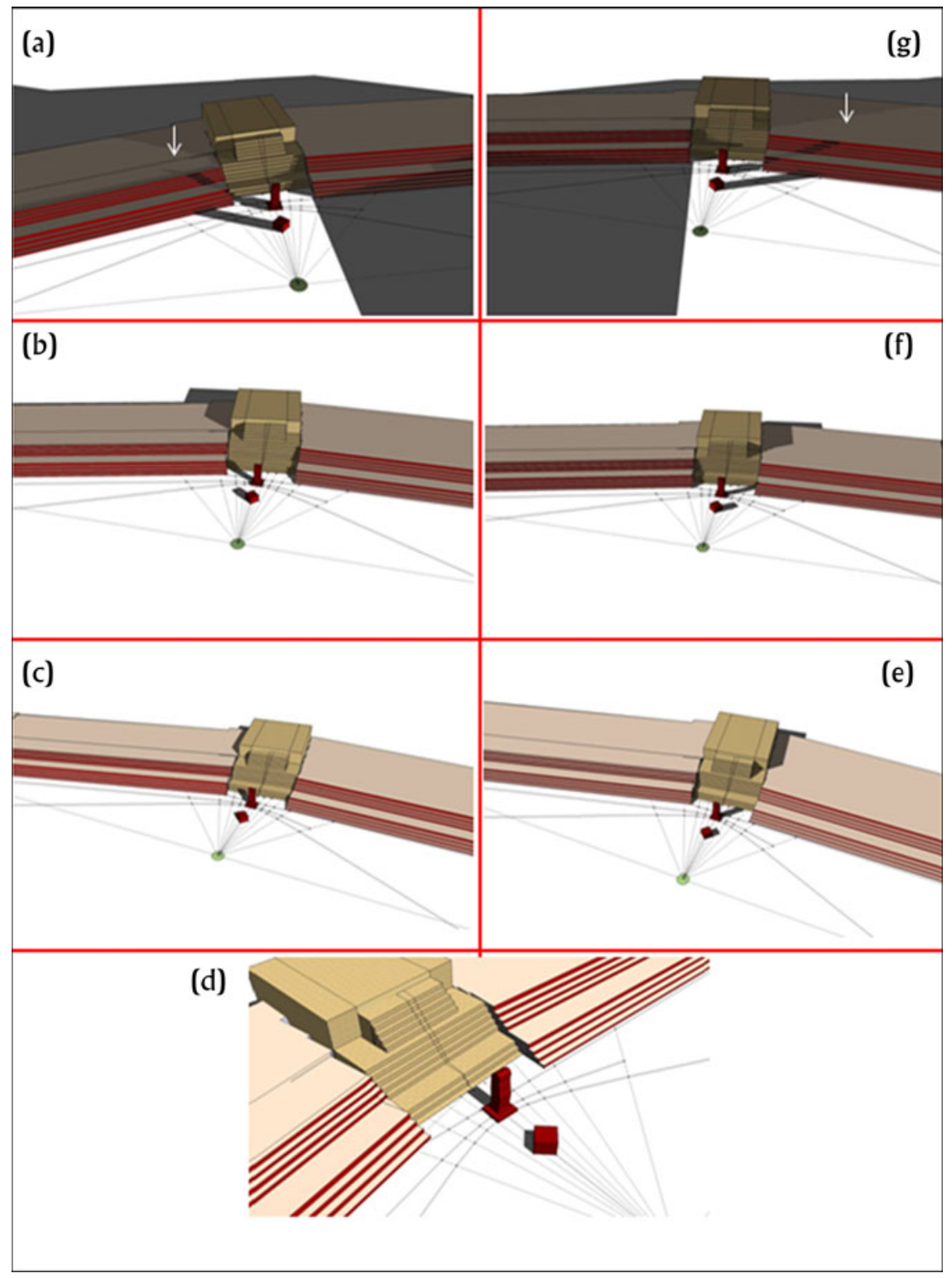

Figure 5. Sequence of images framing a model of Stela D on the day of winter solstice. Before noon, reading from top to bottom: (a) a mark appears at the end of the shadow of Stela D on top of the Northwest Stairway; (b) shadow of Stela D enters the Central Stairway; (c) shadow of Stela D on the west side of the first step of the Central Stairway. At noon: (d) shadow of Stela D at solar noon touching the outer edge of the first step of the Central Stairway. Afternoon: (e) shadow of Stela D on the east of the first steps of the Central Stairway; ( $\mathrm{f}$ ) shadow of Stela D leaving the Central Stairway on the east end of its first steps; (g) a mark appears at the end of the Stela D shadow on top of the Northeast Stairway.

period, the Stela D shadow reduces in size, tilting toward the south eastern end of the Northwest Stairway. From this moment, the end of the shadow starts to delineate a straight line. At solar noon, around 12:04 P.M., the shadow is directly behind Stela D, only this time it is only a quarter of the size compared to the shadow on the day of the winter solstice. The shadow of Stela D reaches the southwest corner of the Northeast Stairway about 4:00 P.M. From here, the end of the shadow remains continuously in contact with the outside edge of the first step of the Northeast Stairway, following this direction until sunset around 6:00 P.M. The alignment of the Northeast Stairway with a line that traces the tip of the shadow of Stela D across the floor of the plaza is evident. Equinox daylight lasts twelve hours. Figures $6 \mathrm{a}-6 \mathrm{~g}$ show a sequence of seven images of the virtual model to show the behaviour of Stela D's shadow on the day of spring (or autumn) equinox.

\section{First (and Second) Zenith Sun Passage}

At any time on the day of the first (or second) zenith sun passage, the shadow of Stela D falls on the Northwest, Central, or the Northeast Stairways of Structure 10L-2. When the first rays of the sun illuminate it for several minutes before 6:00 A.M., the shadows of Stela D project on the West Stairway. Between 6:00 and 8:00 A.M., the stela's shadow, which at first is quite long, reduces in size and its end traces a line parallel to the direction of the Northwest Stairway, although visibly removed from it. In 


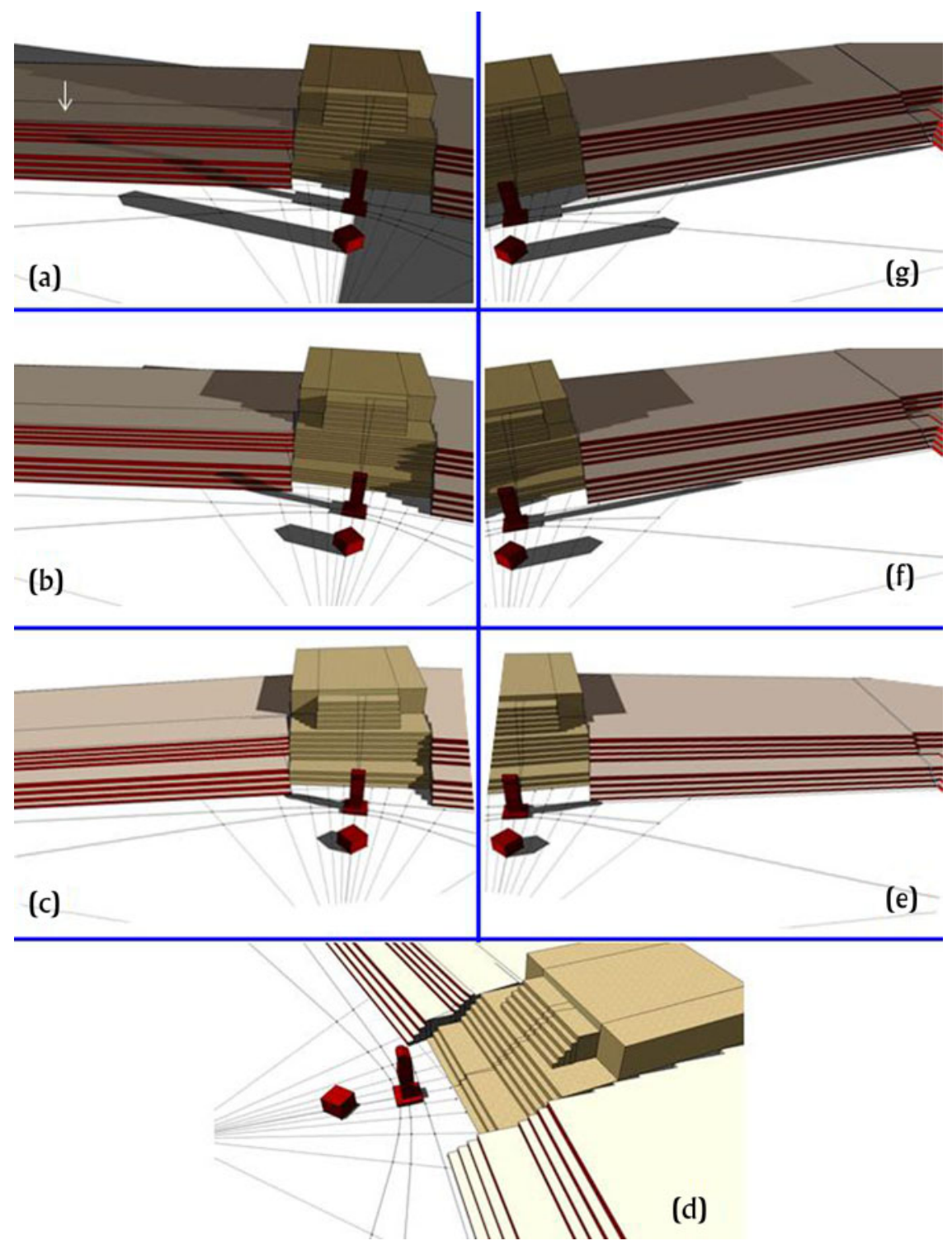

Figure 6. Sequence of images of the Stela D model on the spring (or autumnal) equinox. Before noon: (a) a sign appears at the end of the shadow of Stela D on top of the Northwest Stairway; (b) Stela D shadow on the lower steps of the Northwest Stairway; (c) shadow of Stela D in the southeast of the Northwest Stairway. At noon: (d) shadow of Stela D at solar noon. Afternoon: (e) shadow of Stela D touching the southwest edge of the Northeast Stairway; (f) shadow of Stela D touching the outer edge of the first step of the Northeast Stairway; (g) shadow of Stela D touching the outer edge of the first step of the Northeast Stairway near sunset.

the following four hours, Stela D's shadow constantly shrinks so that, by the half solar day at about 11:54 A.M., the stela does not project shadow in any direction. This absence of shadows lasts a few minutes, sufficient time that allows an observer to walk around the stela and to be able to verify that it does not project a shadow anywhere. After this moment, the shadow appears at the east side of the stela growing slowly in the first four hours and then more rapidly up to the sunset, a few minutes after 6:00 P.M. As it passes in front of the Northeast Stairway it is clear that the shadow elongates until it reaches the East Stairway. The day of the zenith sun passage lasts twelve hours and fifteen minutes. Figures $7 \mathrm{a}-7 \mathrm{~g}$ present seven pictures to illustrate the behaviour of the shadow of Stela D the day of the zenith sun passage.

\section{Summer Solstice}

When the summer solstice day dawns, all structures, platforms, and stairways cast huge shadows toward the south, covering the northern part of the plaza. A quarter of an hour later, when the shadows of the structures and stairways begin to decrease in size, a huge shadow from Stela D appears projected on the West Stairway, a dozen meters away from the west end of the Northwest Stairways. From a few minutes before 6:00 A.M. until about 8:00 A.M., the shadow of Stela D decreases rapidly, maintaining a diagonal direction over the floor of the plaza. In the next three hours, it becomes clear that the shadow is pointing away from the front side of Stela D. At about 11:17 A.M. the tip of the shadow of Stela D touches the southwest corner of its base. At a couple of minutes before 


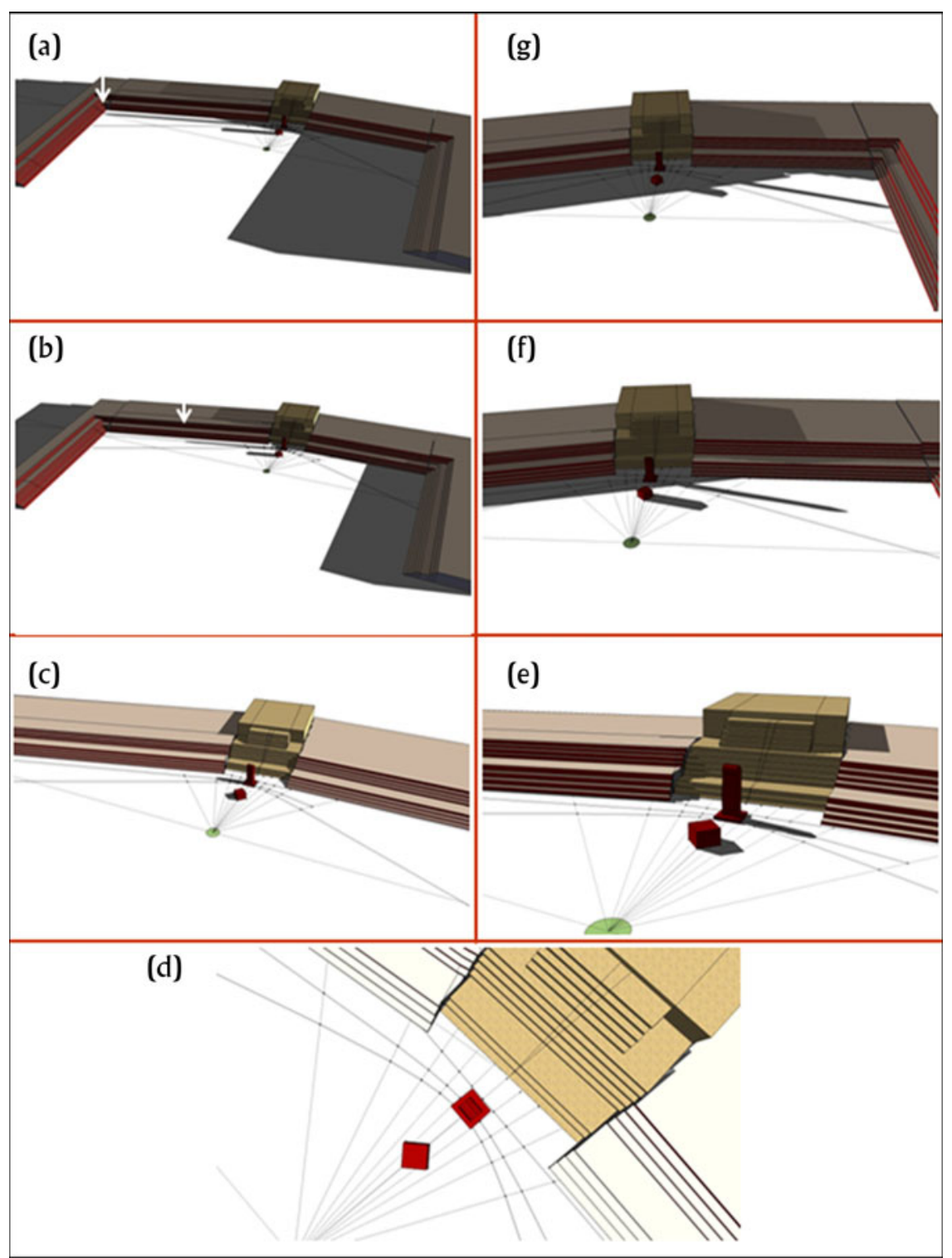

Figure 7. Sequence of images of the model of Stela D on the first (or second) zenith sun passage day. Before noon: (a) a sign appears at the end of the shadow of Stela D touching the lower outer edge of the West Stairway and the floor of the plaza; (b) a sign appears at the end of the shadow of Stela D running parallel to but separate from the Northwest Stairway; (c) shadow of Stela D going against the southeast end of the Northwest Stairways. At noon: (d) at the mean solar day no shadow in any direction. Afternoon: (e) shadow of Stela D on the plaza separated from the Northeast Stairway; (f) shadow of Stela D very far from the Northeast Stairway; ( $g$ ) shadow of Stela D crossing the east side of the plaza and touching the bottom exterior of the East Stairway near sunset.

noon, coming from the south face of Stela $\mathrm{D}$, which is carved with a portrait of the thirteenth ruler of Copan, the shadow runs over the base as an extension of the figure and falls down on the floor of the plaza two centimeters away. This movement draws attention to the small size of the maximum shadow projected towards the south on summer solstice, with respect to the maximum shadow projected to the north on the winter solstice. When trying to precisely measure a distance equal to the size of that great shadow of the winter solstice, one notices the presence of the bicephalic Altar of Stela D. Then the shadow begins to change direction so that by 12:37 P.M., it completely covers the southeast corner of the base of Stela D. From this direction, the shadow of Stela D begins to grow, first slowly and then rapidly, always running on the floor of the plaza until it reaches the bottom of the East Stairway $20 \mathrm{~m}$ beyond the east end of the Northeast Stairway. This is the longest day of the year, lasting nearly thirteen hours. The sun sets at 6:20 P.M. Seven frames of images are presented in Figures $8 \mathrm{a}-8 \mathrm{~g}$ to illustrate the behaviour of Stela D shadows on the summer solstice.

\section{DISCUSSION AND CONCLUSIONS}

The Maya of Copan left important evidence of having been great astronomers and architects. They observed the night and day skies and applied their understanding to building structures and locating monuments such as those found in the Main Plaza of the Copan 


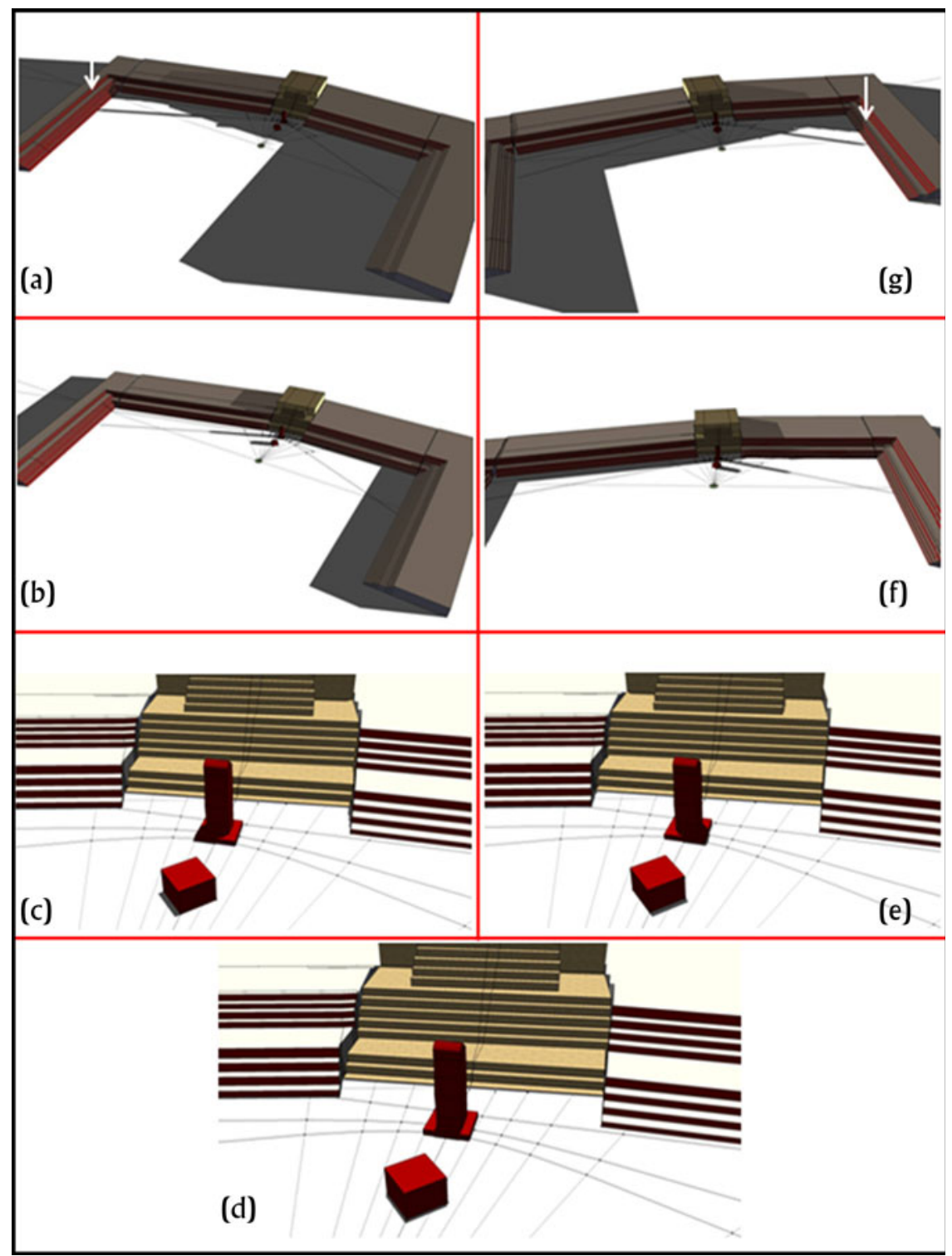

Figure 8. Sequence of images of Stela D the day of the summer solstice. Before noon: (a) a sign at the end of the shadow of Stela D touches the lower outer edge of the West Stairway and the floor of the plaza; (b) shadow of Stela D in the middle of the west side of the plaza; (c) shadow of Stela D on the southwest corner of the base. At noon: (d) shadow of Stela D at solar noon. After noon: (e) shadow of Stela D on the southeast corner of the base; ( $\mathrm{f}$ ) shadow of Stela $\mathrm{D}$ in the middle of the east side of the plaza; (g) shadow of Stela D through the east side of the plaza touching the bottom exterior of the East Stairway.

Ruins Archaeological Park. We think they carefully watched and marked sunrises and sunsets. Since looking directly at the sun is highly dangerous and can cause immediate damage to the eyes, they observed shadow projections throughout the day. These shadows moved like snakes do, for example the very abundant boa constrictor or mazacuata in Mesoamerica (Sandoval and Hellmuth 2009), the species most similar to those carved on Stela D. Probably not all of the Maya followed movements of the shadows with the same attention as did the people directly responsible for performing solar astronomical observations. We believe that these early astronomers were the ones using the stelae as gnomons, learning from their ancestors who used wooden posts as instruments to measure and mark time intervals during the day and dates along the tropical year. We think this was the way the
Maya of Copan measured time and kept track of days, beginning to count them on the winter solstice, that is, the day when at the sunrise shadows of Stela D were moving down from the top of the Northwest Stairway, going down to touch the exterior edge of the first step of the Central Stairway, directly behind Stela D, and then ascending up to the top of the Northeast Stairway. Observations of the shadows continued every day of the year, which was counted and marked in their solar calendar with special care. In addition to the winter solstices, they marked and counted the shadows of the days of equinoxes, solar zenith passages. These days obviously had different patterns that Maya architects marked by the orientation of the stairways with regard to the place where they located Stela D and its altar. Their account of the year they called haab (Rice 2007), at the time when the 

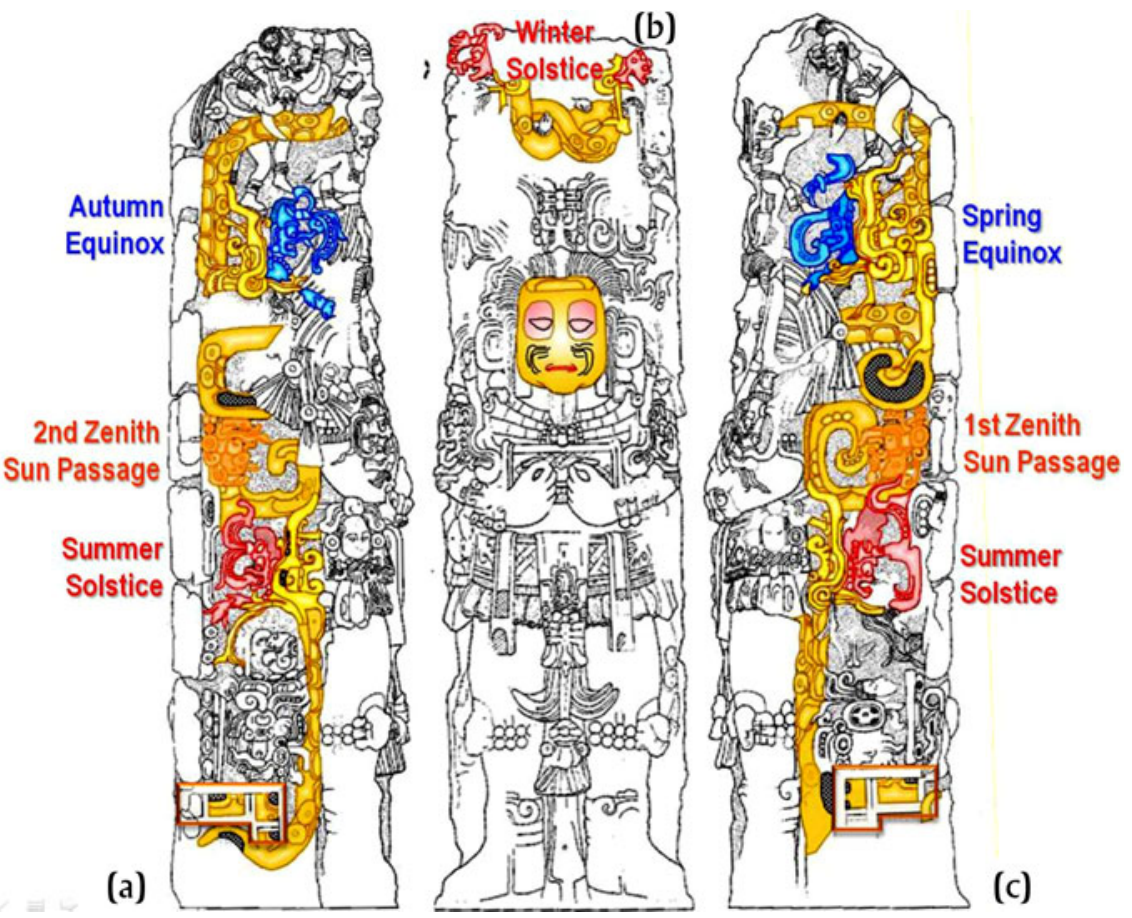

Figure 9. Solar calendar carved into the sides of Stela D: (a) west face, (b) south face; and (c) east face. Based on original drawings by Anne S. Dowd (Baudez 1994).

shadow of Stela D returned to the northern end of the Main Plaza on the day of another winter solstice to begin a new year. Thus they marked the conclusion, or "tied" the years at the end of the haab, symbolized by the intertwining of the snakes associated with the monument's moving shadows.

Aveni and colleagues (2003) examined several hypotheses to explain the way structures were oriented in ancient Maya cities in relation to solar events like equinoxes and solstices in order to mark solar calendars. In the case of the Main Plaza of Copan, the shadows cast by Stela D, moving like snakes as they crossed the astronomically oriented stairways of the Structure 10L-2 and the floor of the plaza's northern sector, mark different dates of the year associated with the major solar events of the haab calendar. This is part of the message carved on the different sides of Stela D.

Stela D portrays on its south face the standing figure of Waxaklajuun Ubaah K'awiil, or 18 Rabbit. Here 18 Rabbit, the thirteenth ruler of Copan, wears a mask with aged facial features that represent the Old Sun God. In Figures 9a-9c, we present the west, south, and east sides of Stela D, as drawn by Anne S. Dowd (Baudez 1994). In each of these views, we emphasize the mask of 18 Rabbit and the bodies of snakes and glyphs associated with the sun that show a calendar of events in the solar tropical year. In correspondence to the jade pectoral carved with a pair of entwined serpents that was deposited in the Structure 10L-2-2nd cache, there are two serpents whose bodies entwine on the summit of the monument's south face, which were held by a nowmissing ancestor or deity figure representing the "binding of the years" on winter solstice. Therefore, the calendar is read starting on top of the south side of Stela D, where the winter solstice is represented by one of the long snakes with the head on the thirteenth ruler headdress, and the body and tail in the upper portion of the east side behind the figure of the ruler. We think that this was an analogy to the behaviour of the shadows of Stela D, which on the winter solstice are projected on top of the Northwest and Northeast Stairways behind the stela but at noon time fall as long shadows on the floor of the plaza directly behind the stela. At this point the sun is to the south on the opposite side, which is to where the solar glyph appears to be emerging from the jaws of the snake.

On the east side of Stela D is the spring equinox represented by another snake, carved behind the head of the ruler, with a shorter body but with the same sinuous line as the previous winter solstice snake. We think this was an analogy to the behaviour of the shadows (a)

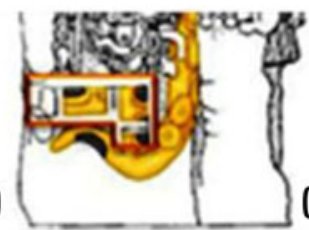

(b)

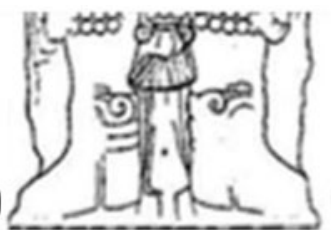

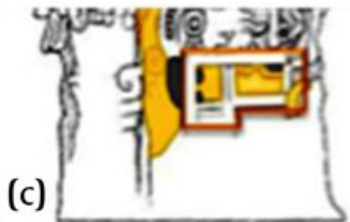

Figure 10. Detail of Stela D, showing "steps." 
of Stela $\mathrm{D}$, which by the end of the day of the spring equinox has long shadows, but at noon casts a much shorter shadow than the shadow that appears on winter solstice. At this time shadows are behind Stela D because the sun is still to the south on the opposite side, and the sun glyph also looks at emerging from the jaws of the serpent.

Moving down the east side, up to the ruler's power sceptre or ceremonial bar, is the first zenith sun passage, an event represented by the body of another coiled snake tail with a reversed glyph creature at the other end. We think this was an analogy to the behaviour of the shadows of Stela D at the ends of the zenith sun passage day, when the shadow has great size. The mean solar day has no shadow because the sun is exactly at the zenith: to see it (the sun), it is necessary to raise one's head so that the creature has its head inverted. We think this reversed glyph is a solar creature, a supernatural manifestation of the sun at noon, when on earth there is only light and no shadows anywhere, not even from the body or jaws of the serpent. The first zenith sun passage is an event that announces that after this day, directions of shadows at noon will change from north to south.

The following event of the solar calendar is the summer solstice, which appears in the lower part of the east and west sides of Stela D, represented by serpents extended toward the front of the ruler, with the head at the height of the belt with the band of the sky and the tail in the lower part of the side within and under glyphs with the form of steps (Figures 9-10). We think that this has an analogy to the patterning of Stela D's shadows on the day of the summer solstice. At the end of the day, the shadows are very long. Later in the morning, approaching midday, the shadow covers the extreme southwest base of Stela $\mathrm{D}$, which we interpret is what is represented in the east side of the stela suggesting that the shaded area is small because the rest of the body of the serpent is buried.

On the half solar day, the short shadow extending as a continuation of the south face of Stela D falls down on the floor of the plaza, exactly two centimeters in front of the base of the stela. In the same direction away from Stela D is the bicephalic altar with a dead skeletal head that looks to the south. At this moment, standing in front of Stela D and its altar, we agree with Baudez (1994:42), who once stated that "[a]n observer looking at both monuments witnesses the main figure on the stela half hidden by the altar; he or she then gets the impression that the figure is sinking into the death head of the bicephalic earth monster." In Figure 11 we represent, drawn over Figure 9, the Old Sun God mask of 18 Rabbit a photograph of the south skeletal dead face of the altar, and a representation of the bodies of serpents and the emergent suns for the different solar events. Continuing with these observations, however, if the observer walks around the altar of Stela D there is a living head that looks to the north, where the ruler is depicted; the sun is, at this point, vertically above the stela. In Figures $12 \mathrm{a}-12 \mathrm{~d}$ we present a sequence of Stela D shadows before noon, at noon, and

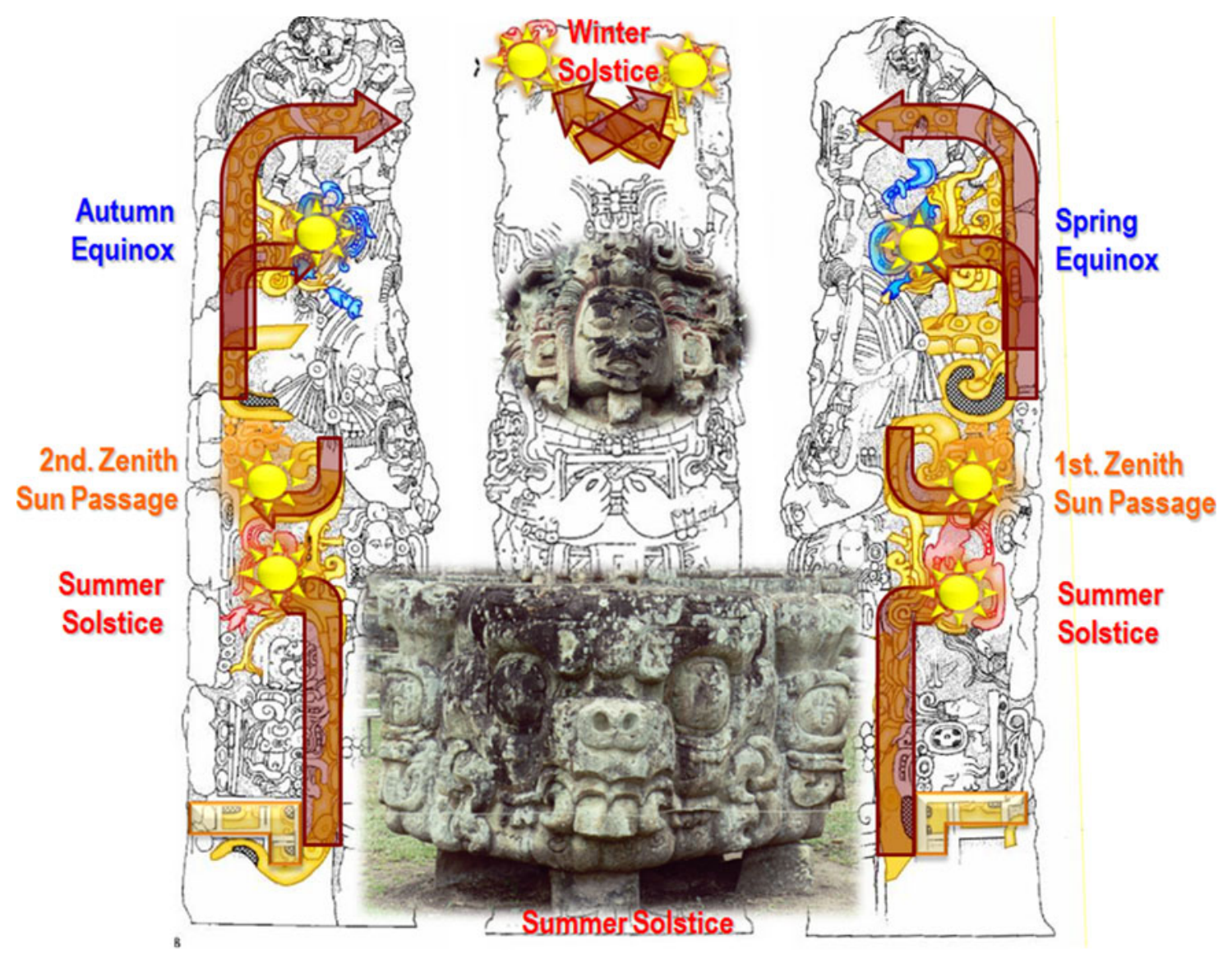

Figure 11. A diagram of the haab solar calendar on Stela D drawn over Figure 9. Bodies of snakes are shown as arrows and solar creatures as suns. Also note 18 Rabbit's mask of the Old Sun God and the southern death head of Stela D altar. Photographs courtesy of: DACA/ SSF/NAUH. 


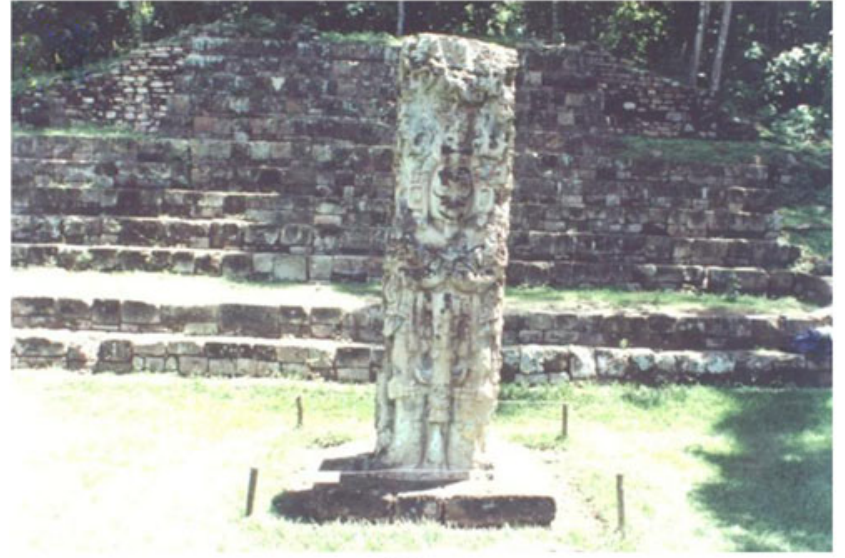

(a)

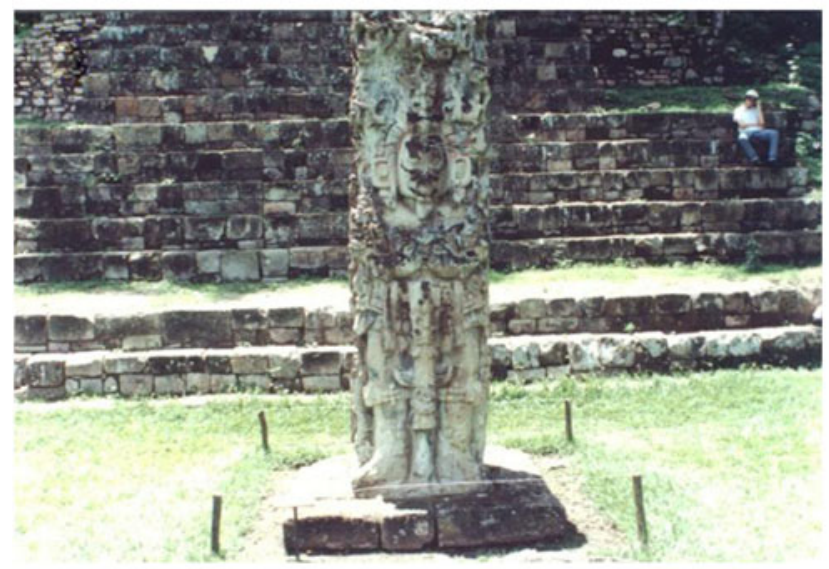

(c)

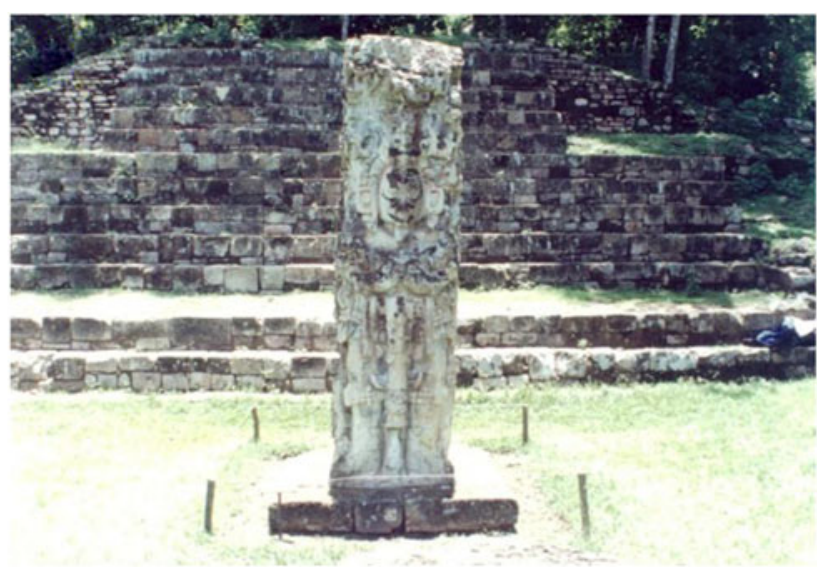

(b)

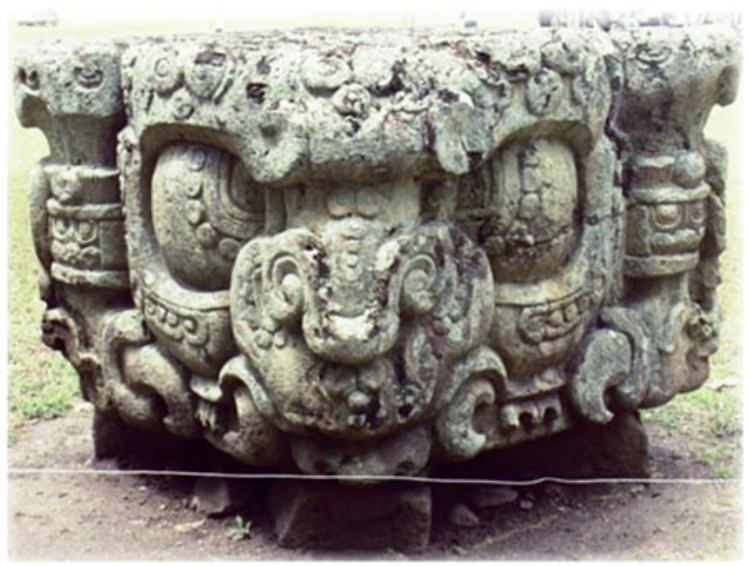

(d)

Figure 12. Images of Stela D and its altar on the summer solstice day: (a) shadow of Stela D on the southwest corner of its base; (b) shadow of Stela D at noon; (c) shadow of Stela D on the southeast corner of its base; (d) northern head of Altar of Stela D. Photographs courtesy of DACA/SSF/NAUH.

in the afternoon, moving south in front of its base, and also the north living head of the bicephalic altar of Stela D.

Soon after midday, the shadow exactly covers the southeast corner of the base of the stela, which is what is represented in the west side of the stela. From the jaws of the serpents on both sides, the solar glyph emerges looking toward the north, which is the position of the sun. All of these elements represent and give great meaning to a solar special event that indicate the summer solstice day as a point of return and a change of directions in the way time is counted and measured compare to the first half of the year.

The reading of the solar events continues on the west side on Stela D where, at the height of the ruler's ceremonial bar, a serpent with the same characteristics as those that appear on the east side represents the second zenith sun passage. As in the case of the first zenith sun passage, we think that this has an analogy with the patterns of shadows cast by Stela D on the day of the second zenith sun passage because they have similar characteristics. However, after the second zenith sun passage day, shadows at noon will point towards the north, opposite the direction to which they point the day after the first zenith sun passage.

The following solar event that appears on the west side is the autumnal equinox represented by a serpent carved behind the head of the ruler with similar characteristics to those of the east face. As with the spring equinox, we think this was an analogy with the behaviour of the shadows of Stela D, which are similar in both equinoxes.

In reading the solar calendar, continuing on the top of the west side and the headdress of the ruler on the south side, another winter solstice represented by another long snake intertwined with the first winter solstice snake and having similar characteristics appears. We think that this is indicative of the closure or "tie up" of the cycle of time that is precisely the tropical year, called by the Maya haab. To complete our reading of the solar calendar we conclude, with the words of Schele and Matthews (1998:169) used to interpret part of the text that is written on the north side of Stela D: "they tied on the Old Sun God headdress." 


\section{RESUMEN}

Los mayas de Copan, Honduras, usaron la Estela D, su altar y las estructuras de sus alrededores como un reloj solar para registrar el tiempo. Investigaciones arqueológicas muestran que en el sector norte de la Plaza Principal del Parque Arqueológico de Copán, existían postes de madera y estelas que pudieron haber sido usadas para medir el tiempo y para realizar ritos asociados. Nosotros construimos un modelo digital de la Estela D para estudiar las sombras proyectadas en diferentes tiempos del día y en diferentes fechas del año tales como solsticios, equinoccios y pasos del sol por el cenit.
El tamaño y orientación de las sombras pudieron haber servido como un marcador del tiempo que los antiguos residentes de Copan utilizaron para mantener registros precisos del año trópico. Nosotros también encontramos evidencia que apoya las interpretaciones iconográficas de una analogía entre los cuerpos de las serpientes que adornan la figura del gobernante en la Estela D, y sus sombras y posiciones del sol en las fechas de eventos solares importantes, las cuales forman un calendario solar que cuenta los años desde el día del solsticio de invierno.

\section{ACKNOWLEDGMENTS}

An oral presentation of this article was made at the 78th Annual Meeting of the Society for American Archaeology (SAA) held 5 April 2013 in Honolulu, Hawai'i in the Fryxell Symposium: Papers in Honour of Anthony F. Aveni. With this article we want to thank Dr. Anthony F. Aveni for motivating

\section{REFERENCES}

Aveni, Anthony F

2001 Skywatchers. Rev. ed. University of Texas Press, Austin.

Aveni, Anthony F., Anne S. Dowd, and Benjamin Vining

2003 Maya Calendar Reform? Evidence from Orientations of Specialized Architectural Assemblages. Latin American Antiquity 14: 159-178.

Baudez, Claude F.

1994 Maya Sculpture of Copan, The Iconography. 1st ed. University of Oklahoma Press, Norman.

Cheek, Charles D.

1983 Introducción a las operaciones en la Plaza Principal. In Introducción a la arqueología de Copán, Honduras, Vol. II, edited by Claude F. Baudez, pp. 11-23. Proyecto Arqueológico Copan, Secretaría de Estado en el Despacho de Cultura y Turismo, Tegucigalpa.

Cheek, Charles D., and Veronica Kennedy Embree

1983 La Estructura 10L-2. In Introducción a la arqueología de Copán, Vol. II, edited by Claude F. Baudez, pp. 93-141. Proyecto Arqueológico Copan, Secretaría de Estado en el Despacho de Cultura y Turismo, Tegucigalpa.

Looper, Matthew G.

2009 The Iconography of Dance. In To Be Like Gods: Dance in Ancient Maya Civilization, edited by M. G. Looper, pp. 70-73. University of Texas Press, Austin.

Miller, Mary E.

1999 Maya Art and Architecture. 1st ed. Thames and Hudson, New York. Newsome, Elizabeth A.

2001 Trees of Paradise and Pillars of the World: The Serial Stela Cycle of “18-Rabbit-God K”, King of Copan. University of Texas Press, Austin.

2003 The "Bundle" Altars of Copan: A New Perspective on Their Meaning and Archaeological Contexts. Ancient America 4:1-72.

Pineda de Carías, María Cristina, and Santos Vito Véliz

2009 Base de datos de eventos solares observados desde la Plaza del Sol people from different parts of the world, especially to us at the Department of Archaeoastronomy and Cultural Astronomy at the Space Sciences Faculty of the National Autonomous University of Honduras. We also want to thank to Eloisa Pollack for her collaboration with the translation. del Parque Arqueológico de Copán Ruinas. Revista Ciencia y Tecnología 4:20-35.

Pineda de Carías, Maria Cristina, Santos Vito Véliz, and Ricardo Agurcia Fasquelle

2002a Acerca de las observaciones del Sol realizadas en la Gran Plaza del Parque Arqueológico de Copán Ruinas, Honduras. Yaxkin: Revista del Instituto Hondureño de Antropología e Historia 21:14-44.

2002b El grande y complejo plan de 18 Conejo para la construcción de la Plaza del Sol en el Parque Arqueológico de Copán Ruinas. Revista del Instituto Hondureño de Antropología e Historia, Cincuenta Años con el Patrimonio Cultural de la Nación, Edición Conmemorativa 50 Aniversario 1952-2002 (Especial):126-134.

2009 Estela D: Reloj solar de la Plaza del Sol del Parque Arqueológico de Copán Ruinas, Honduras. Yaxkin: Revista del Instituto Hondureño de Antropología e Historia XXV:111-138.

Rice, Prudence M.

2007 Maya Calendar Origins: Monuments, Mythistory, and the Materialization of Time. University of Texas Press, Austin.

Sandoval, Priscila, and Nicholas Hellmuth

2009 Serpientes de Guatemala: Zoología e Iconografía. 1st ed. Museo Nacional de Historia Natural Jorge Ibarra, Guatemala City.

Schele, Linda, and Peter Mathews

1998 The Code of Kings, The Language of Seven Sacred Maya Temples and Tombs. Simon \& Schuster, New York.

Sullivan, Woody, Bill Nye, and Emily Lakdawalla

2013 EarthDial Instructions. Electronic document, http://www.planetary. org/explore/projects/earth-dial/instructions.html, accessed February 17, 2013.

Taube, Karl

1988 A Study of Classic Maya Scaffold Sacrifice. In Maya Iconography, edited by Elizabeth P. Benson and Gillette G. Griffin, pp. 330-355. Princeton University Press, Princeton. 